\title{
STRATEGI MEMBANGUN KEPERCAYAAN MASYARAKAT PADA \\ PENDIDIKAN DASAR ISLAM
}

\author{
Mahmud Sani \\ Institut Agama Islam (IAI) Uluwiyah Mojokerto
}

\begin{abstract}
ABSTRAK
Pendidikan dasar Islam (madrasah) yang dirintis oleh Para Wali dalam paparan hitoris terlihat sebagai pendidikan yang konservatif dan jauh dari sentuhan-sentuhan kemajuan. Kondisi tersebut secara alamiah membangun image bahwa pendidikan dasar Islam identik dengan pendidikan yang terbelakang (marginal) yang hanya dikonsumsi oleh rakyat kecil (grassroot). Kondisi demikian, menjadikan Lembaga Pendidikan Dasar Islam tidak dipercaya oleh masyarakat. Strategi membangun kepercayaan masyarakat pada pendidikan dasar Islam dapat dilakukan, antara lain: a) Kejujuran, b) Kualitas pelayanan yang baik, c) Pemimpin yang dipercaya masyarakat, d) Pengembangan sumber daya manusia, dan e) Pameran pendidikan.

Kata Kunci: Strategi, kepercayaan masyarakat, pendidikan dasar Islam
\end{abstract}

\section{A. Pendahuluan}

Ungkapan "tak kenal maka tak sayang, tak sayang maka tak cinta," dapat dimanifestasikan dalam dunia pendidikan. Membangun kepercayaan masyarakat terhadap lembaga pendidikan dasar Islam tidak akanmuncul sebelum lembaga tersebut mengenalkan jati dirinya. Kepercayaan masyarakat akan timbul apabila lembaga pendidikan dasar Islam memiliki prestasi-prestasi yang gemilang, unggul dalam membentuk manusia yang beriman dan bertaqwa,cerdas, memiliki jiwa sosial yang tinggi dan lain-lain. Hal itu merupakan tujuan ideal sebagaimana tertuang dalam Undang-Undang RI Nomor 20 tahun 2003 tentang Sistem Pendidikan Nasional BAB II, pasal 3 yang 
berbunyi:

Pendidikan Nasional berfungsi mengembangkan kemampuan dan membentuk watak serta peradaban bangsa yang bermartabat dalam rangka mencerdaskan kehidupan bangsa, bertujuan untuk berkembangnya potensi peserta didik agar menjadi manusia yang beriman dan bertakwa kepada Tuhan Yang Maha Esa, berakhlak mulia, sehat, berilmu, cakap, kreatif, mandiri, dan menjadi warga negara yang demokratis serta bertanggung jawab. ${ }^{1}$

Prestasi dan keunggulan akan dijadikan produk utama bagi setiap lembaga pendidikan yang ingin menjadikan dirinya terdepan. Prestasi dan keunggulan pendidikan yang perlu dikedepankan berkaitan dengan prestasi siswa dalam bidang akademik dan non akademik dengan harapan agar masyarakat tertarik dan memberikan kepercayaan penuh pada lembaga pendidikan dasar Islam, kemudian mempercayakan pendidikan putra-putrinya pada lembaga yang unggul tersebut.

Sampai saat ini, cita-cita membangun kepercayaan masyarakat yang kokoh terhadap lembaga pendidikan dasar Islam (LPDI), terkesan masih menyisakan banyak problem dalam realisasinya. Problema administrasi dan manajemen, minimnya sarana dan prasarana, profesionalisasi guru dan tenaga kependidikan yang masih lemah, transparansi dan akuntabilitas lembaga yang terseok-seok, perspektif kurikulum yang perlu dikaji ulang, serta anggaran dana yang relatif minim, maupun kualitas lulusannya yang masih jauh dari harapan/ kualitas ilmu pengetahuan umumnya, dan lain-lain, merupakan sederet problem LPDI yang menggerus kepercayaan masyarakat yang tangguh.

Dari sederet masalah dalam membangun kepercayaan masyarakat tersebut, salah satunya adalah masih lemahnya bangunan strategi yang dipilih dan direalisasikan LPDI. Strategi yang dijalankan masih belum banyak yang realistis-visioner, juga belum mampu memikat hati masyarakat untuk mempercayai LPDI. Pembahasan

\footnotetext{
${ }^{1}$ Dirjen Pendis, Undang-Undang dan Peraturan Pemerintah RI tentang Pendidikan, (Jakarta: Dirjen Pendis Departemen Agama RI, 2006), 8-7.
} 
tulisan ini akan mengupas lebih tajam tentang strategi membangun kepercayaan masyarakat pada pendidikan dasar Islam. Pembahasan akan dibagi menjadi tiga bagian, yaitu pertama, sekilas sejarah pendidikan Islam; kedua, kepercayaan masyarakat, dan ketiga, strategi membangun kepercayaan masyarakat pada pendidikan dasar Islam.

Latar belakang perlunya lembaga pendidikan dasar Islam (LPDI) menyusun strategi membangun kepercayaan masyarakatadalah, agar masyarakat yang selama ini memiliki anggapan bahwa LPDI kurang layak, terkesan "asal-asalan" dalam mendidik anak menjadi hilang. Oleh karena itu, LPDI harus menampilkan dirinya bahwa LPDI dapat mencetak manusia yang berkualitas.

\section{B. Sekilas Sejarah Pendidikan Islam}

Secara hitoris, pendidikan dasar Islam pada masa lalu terkesan sebagai pendidikan konservatif dan jauh dari kemajuan, karenanya identik dengan pendidikan terbelakang (marginal), konsumsi rakyat kecil (grassroot) dan diselenggarakan apa adanya. Image tersebut bersumber dari kondisi penyelenggaraan pendidikan dasar Islam yang pada awalanya dikenal dengan nama Pesantren, ${ }^{2}$ yang telah dirintis berdirinya oleh para wali. Pesantren pada perkembangannya menghadapi banyakrintangan ${ }^{3}$ dengan datangnya penjajah Belanda yang ingin mengambil alih posisi pendidikan Islam untuk dijadikan tempat mencetak tenaga kerja murahan untuk kepentingan Belanda. Walaupun mengalami kegagalan, namun hal itu menjadikan Belanda beinisiatif mendirikan lembaga pendidikan sendiri. Inilah bibit munculnya sekolah umum yang mengalami peningkatan pesat pada saat Idonesia merdeka karena dikelola oleh pemerintah yang berorientasi pada pengembangan masyarakat, seperti mencetak pegawai atau tenaga kerja yang

\footnotetext{
2Djumhur dan Danasaputra, Sejarah Pendidikan Islam, (Bandung:IImu, 1990), 112.

${ }^{3}$ Imam Bawani, Segi-Segi Pendidikan Islam, (Surabaya: Al-Ikhlas, 1987), 49.
} 
dibutuhkan oleh masyarakat dan dunia kerja ${ }^{4}$, sementara pesantren dan madrasah saat itu tidak mengalami perubahan bahkan statis.

Untuk mengatasi persoalan kesenjangan antara pendidikan umum dan pendidikan islam, pemerintah berusaha menyeragamkannya dengan mengeluarkan surat keputusan bersama tiga menteri tahun 1975. Isinya menyangkut harapan mutu madrasah dapat sejajar dengan sekolah umum, karena kualitas madrasah sangat jauh jika dibandingkan dengan pendidikan umum (pada waktuitu) ${ }^{5}$. Pelaksanaan SKB tiga menteri tersebut merupakan persoalan karena siswa madrasah harus menguasai dua jenis mata pelajaran sekaligus, padahal jumlah mata pelajaran agama sudah sangat banyak, sementara itu, alokasi waktu yang diberikan sama. Beban kurikulum yang amat berat bagi madrsah tersebut menyebabkan rendahnya kualitas siswa dalam menguasai mata pelajaran agama islam khususnya mata pelajaran Bahasa Arab.

Keadaan tersebut menyebabkan masyarakat mempunyai image bahwa lembaga pendidikan agama, termasuk pendidikan dasar Islam cenderung terbelakang dan jauh yang diharapkan. Image tersebut berdasarkan faktor-faktor "Di antaranya yaitu tidak terpenuhinya maksud pemerintah dalam melaksanakan pembangunan dalam sector agama, khususnya agama Islam. Faktor lain yaitu adanya anggapan bahwa lulusan sekolah agama khususnya sarjananya dipandang bergengsinya lebih rendah dibandingkan sarjana umum misalnya para insinyur, dokter dan lainnya, yang dipandang memiliki masa depan jauh lebih baik daripada sarjana-sarjana agama"6.

Oleh karena itu, masyarakat enggan untuk menitipkan putraputrinya kelembaga pendidikan, bahkan mempercayakan pendidikan putra-putrinya keluar negeri yang bukan lembaga pendidikan islam

\footnotetext{
${ }^{4}$ Ibid, hal. 49.

${ }^{5}$ Nurul Yaqien, "Membangun Kepercayaan Masyarakat Pada Madrasah Melalui Pameran Pendidikan", dalam jurnal Madrasah, Volume 11, Nomor 2, Januari-Juni 2010, 194.

${ }^{6}$ Ahmad Mustofa dan Abdullah Ali, Sejarah Pendidikan Islam di Indonesia, (Bandung: CV. Pustaka Setia, 1997), 151.
} 
karena; 1) bisa langsung merasakan pergaulan internasional, 2) menguasai bahasa Inggris dan modal bagi pergaulan internasional yang lebih baik, 3) merupakan investasi pendidikan karena denganbersekolah di luar negeri mereka akanmembawa keuntungan ketika kembali ke Indonesia karena dihargai tinggi saat bekerja serta dapat mengamalkan ilmunya ${ }^{7}$.

Sejarah sosial lembaga pendidikan Islam demikian yang menjadikan image madrasah jatuh, maka madrasah perlu segera merubah pandangan masyarakat bahwa madrasah juga merupakan pendidikan yang maju dan berkualitas bahkan memiliki kelebihan jika dibandingkan dengan sekolah umum, di antaranya merupakan pendidikan yang diselenggarakan dan dikembangkan dari semangat manifestasi ajaran dan nilai-nilai Islam, serta mendasarkan seluruh aktivitas pembelajarannya pada ranah ketauhidan, ${ }^{8}$ yang berfungsi untuk menyiapkan manusia sebagai khalifah yang mewakili Tuhan di muka bumi. Manusia yang mengorientasikan hidupnya bukan saja untuk kemaslahatan dunia, tetapi secara transendental menautkan segala aktivitas keduniawian sebagai bekal kehidupan yang lebih abadi di akhirat.

\section{Strategi Membangun Kepercayaan Masyarakat Pada Pendidikan Dasar Islam}

Strategi berarti rencana yang cermat mengenai kegiatan untuk mencapai sasaran yang khusus. ${ }^{9}$ Istilah strategi semula bersumber dari kalangan militer dan dinyatakan sebagai kiat yang digunakan oleh para jenderal untuk memenangkan suatu peperangan. ${ }^{10}$ Adapun strategi membangun kepercayaan masyarakat pada pendidikan dasar

\footnotetext{
${ }^{7}$ Nurul Yaqien, Membangun Kepercayaan......, 196.

${ }^{8}$ Abudin Nata, Manajemen Pendidikan, (Jakarta: Kencana Prenada Media Group, 2012), 198.

9 Pusat Bahasa Departemen Pendidikan Nasional, Kamus Besar Bahasa Indonesia, (Jakarta: Balai Pustaka, 2001). 708.

${ }^{10}$ Sondang P. Siagian, Manajemen Stratejik, (Jakarta: Bumi Aksara, 1995), 15.
} 
Islam sebagaimana gambar berikut.

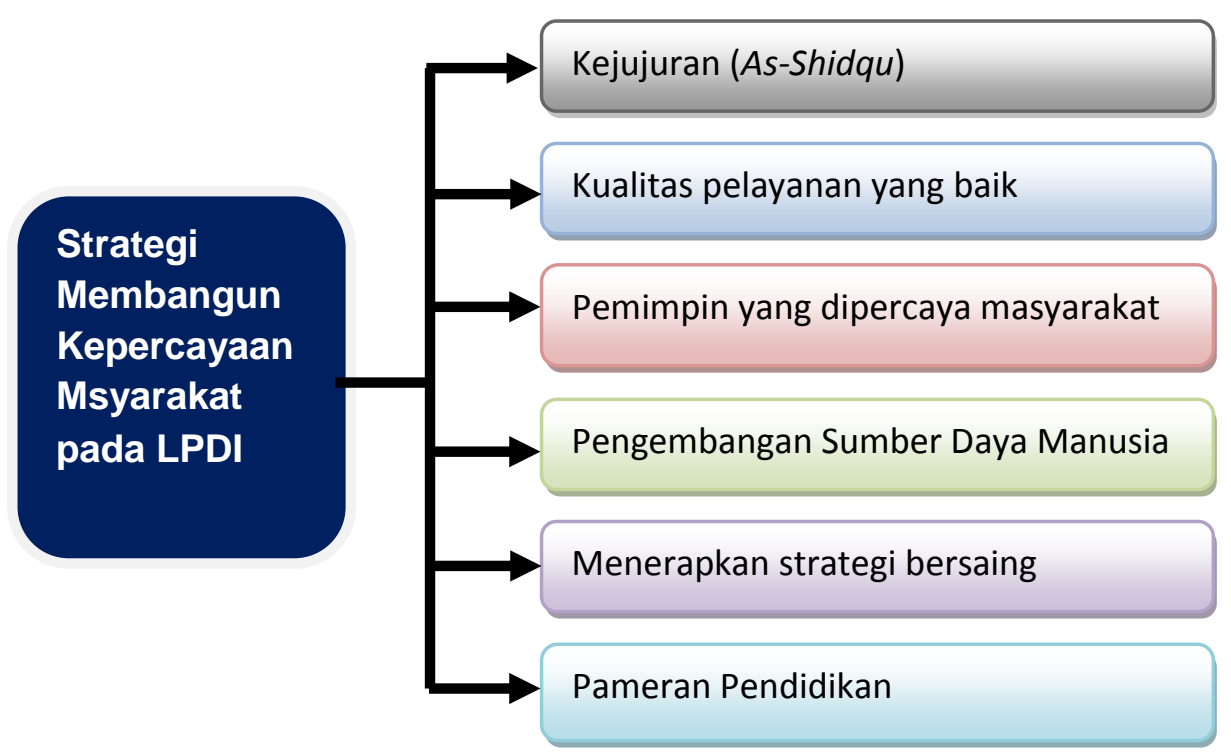

Gambar 1: Strategi Membangun Kepercayaan Masyarakat Pada Lembaga

Pendidikan Dasar Islam (LPDI)

\section{Kejujuran (As-Shidqu)}

Sikap jujur dan patuh terhadap standar etika pendidikan dapat menumbuhkan rasa saling percaya, saling menghormati di antara para pelaku pendidikan yang pada gilirannya akan berdampak pada efisiensi dalam berusaha serta menciptakan iklim persaingan yang sehat serta kepentingan semua pihak yang terkaitakan dapat dilayani dengan puas tanpa ada benturan.

Dari Ibnu Mas'ud r.a Nabi saw, beliau bersabda: "Sesungguhnya kejujuran akan membimbing pada kebaikan, dan kebaikan itu akan membimbing ke Surga, sesungguhnya jika seseorang yang senantiasa berlaku jujur hingga ia akan dicatat sebagai orang yang jujur. Dan sesungguhnya kedustaan itu akan mengantarkan pada kejahatan, dan sesungguhnya kejahatan itu akan mengiring ke Neraka. Dan sesungguhnya jika seseorang yang selalu berdusta sehingga akan dicatat baginya sebagai seorang pendusta”. (HR. Mutafaq 'alaih) 
Kejujuran (kebenaran) ialah nilai dari keutamaan yang utama dan pusat akhlak, dimana dengan kejujuran segala urusan menjadi tertib dan perjalanannya menjadi mulia. Kejujuran akan mengangkat harkat pelakunya menjadi orang terpercaya, pembicaraannya disukai, dicintai orang-orang, ucapannya diperhitungkan oleh penguasa, dan persaksiannya diterima di pengadilan. Alloh memerintahkan melalui firman-Nya dalam suratAl-Taubah ayat 119 .

Hai orang-orang yang beriman bertakwalah kepada Allah, dan hendaklah kamu bersama orang-orang yang benar.(QS. At-Taubah: 119)

Jujur adalah istilah untuk mengungkapkan hakikat sesuatu yang berwujud dan kejadian yang sesuai dengan kenyataannya.Macam-macam kejujuran yaitu: a) Jujur dalamberbicara, Rasul SAW. bersabda:

"Suatu khianat besar bila kamu berbicara kepada kawanmu dan dia mempercayai kamu sepenuhnya padahal dalam pembicaraan itu kamu berbohong kepadanya". (HR. Ahad dan Abu Dawud) ${ }^{11}$

b) Jujur dalam niat dankehendak, c) Jujur dalam berkeinginan dan dalam merialisasikan, d) Jujur dalambertindak.

\section{Kualitas Pelayanan yang Baik}

Kualitas pelayanan menurut Goetsch dan Davis sebagaimana dikutip Lembaga Administrasi Negara Republik Indonesia, adalah suatu kondisi dinamis yang berhubungan dengan produk, jasa, manusia, proses dan lingkungan yang memenuhi atau melebihi harapan. Kualitas pelayanan juga berhubungan dengan terpenuhinya harapan/kebutuhan pelanggan ${ }^{12}$. Dalam kaitannya dengan pelayanan kepada pelanggan eksternal, keberadaan konsumen yang setia merupakan pendukung

\footnotetext{
${ }^{11}$ Muhammad Faiz al-Math, 1100 Hadits Terplih: Sinar Ajaran Muhammad, terj. A. Aziz Salim Basyarahil. Dari judul Asli Qabasun Min Nuri Muhammad. (Jakarta: Gema Insani Press, 1994), 278.

${ }^{12}$ Lembaga Administrasi NegaraRI, Strategi Peningkatan Kualitas Pelayanan Publik, (Jakarta: LAN RI, 2006), 16.
} 
kesuksesan lembaga pendidikan dasar Islam (LPDI) karenanya LPDI harus menempatkan konsumen pendidikan sebagai aset berharga, karena tidak ada LPDI yang bertahan bila ditinggalkan oleh pelanggannya. ${ }^{13}$

\section{a. Ciri-Ciri Pelayanan YangBaik}

Ciri pelayanan yang baik dalam melayani pelanggan adalah. ${ }^{14}$

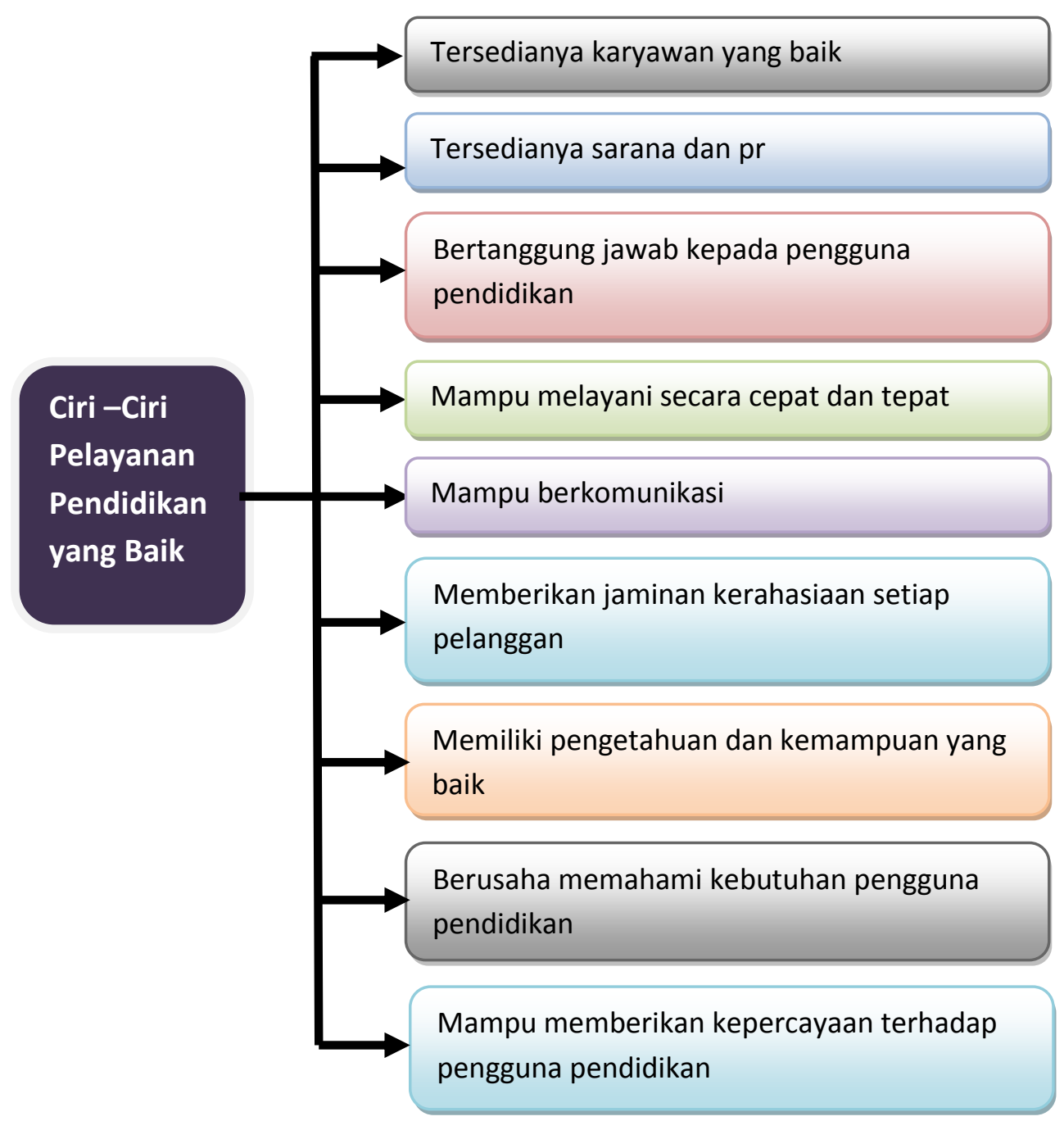

Gambar 2: Ciri-ciri Pelayanan Pendidikan yang Baik

\footnotetext{
${ }^{13}$ Rayendra L. Toruan, Dasar-Dasar Pelayanan Prima. (Jakarta: PT Elex Media Komputindo, 2004), 22.

${ }^{14}$ Kasmir, Etika Customer Service. (Jakarta: Raja Grafindo Perssada, 2011), 34.
} 
1) Tersedianya karyawan yang baik, yaitu karyawan yang ramah, sopan, dan menarik, cepat tanggap, pandai bicara, menyenangkan, rapi, cepat, dan cekatan serta pintar. Allah SWT. Berfirman:

Maka disebabkan rahmat dari Allah-lah kamu Berlaku lemah lembut terhadap mereka.Sekiranya kamu bersikap keras lagi berhati kasar, tentulah mereka menjauhkan diri dari sekelilingmu.(QS. Al-Imran: 159)

2) Tersedianya sarana dan prasarana yangbaik

Pada dasarnya pengguna pendidikan ingin dilayani secara prima.Untuk melayani mereka, salah satu hal yang paling penting diperhatikan, di samping kualitas dan kuantitas sumber daya manusia adalah sarana dan prasarana yang dimiliki LPDI. Peralatan dan fasilitas yang dimiliki seperti ruang tunggu dan ruang untuk menerima tamu harus dilengkapi berbagai fasilitas lain sehingga membuat pelanggan nyaman atau betah dalam ruangan tersebut. ${ }^{9}$

3) Bertanggung jawab kepadapengguna pendidikan

Bertanggung jawab kepada setiap pengguna pendidikan sejak awal hingga selesai artinya dalam menjalankan kegiatan pelayanan karyawan harus mampu melayani dari awal sampai tuntas atau selesai. Pengguna pendidikan akan merasa puas jika karyawan bertanggung jawab terhadap pelayanan yang diinginkan.

Allah Swt. berfirman:

Hai orang-orang yang beriman, janganlah kamu mengkhianati Allah dan Rasul (Muhammad) dan (juga) janganlah kamu mengkhianati amanat-amanat yang dipercayakan kepadamu, sedang kamu mengetahui. (QS. Al-Anfal: 27)

4) Mampu melayani secara cepat dan tepat

Mampu melayani secara cepat dan tepat artinya dalam melayani pengguna pendidikan diharapkan karyawan harus melakukannya sesuai prosedur. Melayani secara cepat artinya melayani dalam batasan waktu yang normal. Proses yang terlalu lama dan berbelit akan membuat mereka menjadi tidak betah dan 
malas untuk behubungan kembali.

(yaitu) buatlah baju besi yang besar-besar dan ukurlah anyamannya; dan kerjakanlah amalan yang saleh. Sesungguhnya aku melihat apa yang kamu kerjakan.(QS. Saba': 11)

5) Mampuberkomunikasi

Mampu berkomunikasi artinya karyawan harus mampu berbicara kepada setiap pengguna pendidikan. Karyawan juga harus mampu dengan cepat memahami kenginan mereka. Komunikasi harus dapat membuat pelanggan senggang sehingga jika merekamempunyai masalah, mereka tidak segan-segan mengemukakan kepada petugas. Mampu berkomunikasi juga akan membuat permasalahan menjadi jelas sehingga tidak timbul salah paham.

Rasulullah SAW. bersabda yang artinya:

"Barangsiapa beriman kepada Allah dan hari akhir hendaklah berbicara yang baik-baik atau diam." (HR. Buhari $^{15}$

6) Memberikan jaminan kerahasiaan setiappelayanan

Memberikan jaminan kerahasiaan setiap pelayanan artinya karyawan harus menjaga kerahasiaan pengguna pendidikan yang berkaitan dengan uang dan pribadi. Pada dasarnya menjaga rahasia pengguna pendidikan sama artinya dengan menjaga rahasia lembaga pendidikan. Karena menjaga rahasia pengguna pendidikan merupakan ukuran kepercayaan mereka kepada lembaga pendidikan. Berkaitan dengan memberikan jaminan kerahasiaan ini Allah SWT. berfirman:

Sesungguhnya orang-orang yang ingin agar (berita) perbuatan yang amat keji itu tersiar di kalangan orangorang yang beriman, bagi mereka azab yang pedih di dunia dan di akhirat.dan Allah mengetahui, sedang, kamu tidak mengetahui. (QS. An-Nuur: 19)

$\overline{{ }^{15} \text { Muhammad Faiz al-Math, } 1100}$ Hadits..... 298. 
7) Memiliki pengetahuan dan kemampuan yang baik

Untuk menjadi karyawan yang khusus melayani pelanggan harus memiliki pengetahuan dan kemampuan tertentu.Karena tugas karyawan selalu berhubungan dengan manusia, karyawan perlu dididik khusus mengenai kemampuan dan pengetahuannya untuk menghadapi pengguna pendidikan atau kemampuan dalam bekerja. Kemampuan dalam bekerja akan mampu mempercepat proses pekerjaan.

8) Berusaha memahami kebutuhanpengguna pendidikan

Berusaha memahami kebutuhan pengguna pendidikan artinya karyawan harus cepat tanggap terhadap apa yang diinginkan oleh mereka. Karyawan yang lambat akan membuat pengguna pendidikan lari.

Dari Ibni mas'ud R.A, beliau berkata : Rasulullah SAW bersabda : "Hati manusia itu lebih telah diciptakan menurut fitrahnya, yaitu mencintai orang yang berbuat baik dan membenci orang yang berbuat jelek padanya. (H.R AlBaihaqi).

9) Mampu memberikan kepercayaan terhadappengguna pendidikan

Kepercayaan calon pengguna pendidikan kepada LPDI mutlak diperlukan sehingga calon pengguna pendidikan mau menjadi pengguna pendidikan yang bersangkutan. Demikian pula pengguna pendidikan yang lama perlu dijaga kepercayaannya agar mereka tersebut tidak meninggalkan lembaga pendidikan. ${ }^{16}$

\section{b. Dimensi Kualitas Pelayanan}

Pada dasarnya pelayanan terhadap pelanggan tergantung dari latar belakang karyawan.Supaya pelayanan berkualitas dan memiliki keseragaman, kualitas yang diberikan harus sesuai dengan standar tertentu. Terdapat lima determinan dalam menentukan jasa, yaitu ${ }^{17}$ :

\footnotetext{
${ }^{16}$ Ibid, 37

${ }^{17}$ Ibid, 41.
} 


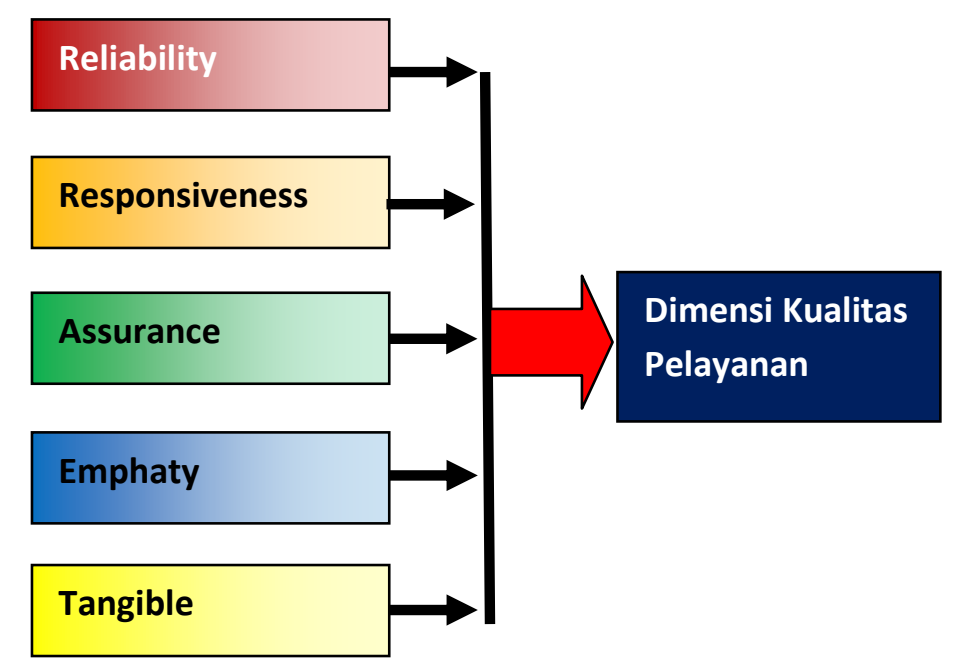

\section{Gambar 3. Dimensi Kualitas Pelayanan}

1) Reliability (keandalan)

Dimensi ini menunjukkan kemampuan lembaga pendidikan untuk memberikan pelayanan secara akurat, handal, dan bertanggung jawab sesuai yang dijanjikan dan terpercaya. Kualitas pelayanan ini umumnya terlihat dalam kerja sehari-hari, misalnya jika pada waktu tertentu terdapat kesalahan, hal ini akan memberikan indikasi kualitas pelayanan yang menurun, contohnya ketepatan waktu dan kecepatan dalam melayani pengguna pendidikan.

2) Responsiveness (ketanggapan)

Dimensi ini mencakup keinginan untuk membantu pelanggan dan memberikan yang tepat dan cepat. Tingkat kepekaan yang tinggi terhadap pengguna pendidikan diikuti dengan tindakan yang tepat sesuai dengan kebutuhan tersebut.

3) Assurance (jaminan dan kepastian)

Pengetahuan dan kesopanan karyawan untuk menimbulkan kepercayaan dan keyakinan, atau jaminan ini dapat ditunjukkan melalui pengetahuan, kesopan santunan, rasa aman, rasa percaya, bebas dari bahaya dan resiko yang dapat diberikan karyawan kepada pelanggannya. 
4) Empathy (empati)

Memberikan perhatian yang tulus dan bersifat invidual atau pribadi yang diberikan kepada para pengguna pendidikan dengan berupaya memahami keinginan mereka. Di mana suatu lembaga pendidikan memiliki pengertian dan pengetahuan tentang pengguna pendidikan, memahami kebutuhan mereka secara spesifik, serta memiliki waktu pengoperasian bagi pengguna pendidikan. Nabi SAW. Bersaabda yang artinya:

"Di antara akhlak seorang mukmin adalah berbicara dengan baik, bila mendengarkan pembicaraan tekun, bila berjumpa orang dia menyambut dengan wajah ceria dan bila berjanji ditepati." (HR. Addailami) ${ }^{18}$

5) Tangible (berwujud)

Yaitu kemampuan lembaga pendidikan dalam menunjukkan eksistensinya kepada pihak eksternal melalui sarana dan prasarana yang dapat diandalkan, ${ }^{19}$ meliputi fasilitas fisik, teknologi serta performa pegawai.

Kualitas pelayanan ditentukan oleh pihak yang melayani yang dilayani, sehingga diukur berdasarkan terpenuhinya harapanharapan mereka. ${ }^{20}$ Kualitas layanan ada 2 macam yaitu: a) Kualitas layanan internal, yang dipengaruhi: 1) Pola manajemen, 2) Kesediaan fasilitas pendukung, 3) Pengembangan SDM, 3) Iklim kerja dan keselarasan hubungankerja, 4) Polainsentif. b) Kualitas layanan eksternal, yang ditentukan oleh: 1) Polalayanan dan tata cara penyediaan jasapendidikan. 2) Pola layanan distribusi jasa pendidikan, 3) Pola layanan penjualan jasa pendidikan, 4) Pola layanan dalam penyampaian jasa pendidikan

\footnotetext{
${ }^{18}$ Muhammad Faiz al-Math, 1100 Hadits.....258.

${ }^{19}$ Ratmino dan Atij Septi Winarsih, Manajemen Pelayanan, (Yogyakarta: Pustaka Pelajar, 2009), 5 .

${ }^{20}$ Rayendra L. Toruan, Dasar-Dasar..., 36.
} 
Tabel 1

Sasaran Manfaat Keunggulan Layanan

\begin{tabular}{|c|c|c|c|}
\hline \multirow{2}{*}{$\begin{array}{c}\text { Sasaran } \\
\text { Keunggulan } \\
\text { Layanan }\end{array}$} & \multicolumn{3}{|c|}{ Manfaat Keunggulan Layanan } \\
\hline & Bagi Pengguna & Bagi Karyawan & $\begin{array}{c}\text { Bagi Lembaga } \\
\text { Pendidikan }\end{array}$ \\
\hline $\begin{array}{l}\text { Memutuskan } \\
\text { Pengguna } \\
\text { pendidikan }\end{array}$ & $\begin{array}{l}\text { Kebutuhan } \\
\text { Terpenuhi }\end{array}$ & Lebih percaya diri & $\begin{array}{l}\text { Meningkatkan } \\
\text { citra profesional }\end{array}$ \\
\hline $\begin{array}{l}\text { Meningkatkanl } \\
\text { oyalitas } \\
\text { pengguna } \\
\text { pendidikan }\end{array}$ & $\begin{array}{l}\text { Merasa dihargai } \\
\text { dan } \\
\text { mendapatkan } \\
\text { layanan yang baik }\end{array}$ & $\begin{array}{l}\text { Tercipta kepuasan } \\
\text { pribadi }\end{array}$ & $\begin{array}{l}\text { Kelangsungan } \\
\text { proses pendidikan } \\
\text { Terjamin }\end{array}$ \\
\hline $\begin{array}{l}\text { Meningkatkan } \\
\text { serapan } \\
\text { lulusan } \\
\text { danjasa }\end{array}$ & $\begin{array}{l}\text { Merasa dihargai } \\
\text { dan } \\
\text { mendapatkan } \\
\text { layanan yang } \\
\text { baik }\end{array}$ & $\begin{array}{l}\text { Menambah } \\
\text { ketenagakerjaa } \\
\mathrm{n}\end{array}$ & $\begin{array}{l}\text { Mendorong } \\
\text { masyarakat untuk } \\
\text { berhubungan } \\
\text { dengan } \\
\text { Lembaga } \\
\text { pendidikan }\end{array}$ \\
\hline $\begin{array}{l}\text { Meningkatkan } \\
\text { pendapatan } \\
\text { lembaga } \\
\text { pendidikan }\end{array}$ & $\begin{array}{l}\text { Merasa } \\
\text { menemukan } \\
\text { lembaga } \\
\text { pendidikan yang } \\
\text { revolusioner }\end{array}$ & $\begin{array}{l}\text { Memupuk } \\
\text { semangat untuk } \\
\text { menitikarir }\end{array}$ & $\begin{array}{l}\text { Mendorong } \\
\text { kemungkina } \\
\text { n ekspansi } \\
\text { lembaga } \\
\text { pendidikan. }\end{array}$ \\
\hline
\end{tabular}

Keberhasilan mengembangkan dan melaksanakan pelayanan pendidikan tidak terlepas dari kemampuan dalam pemilihan konsep pendekatannya.Barata mengembangkan pola pelayanan pendidikan berdasarkan konsep 3A, yaitu attitude (sikap), 
attention (perhatian), dan action (tindakan) ${ }^{21}$.

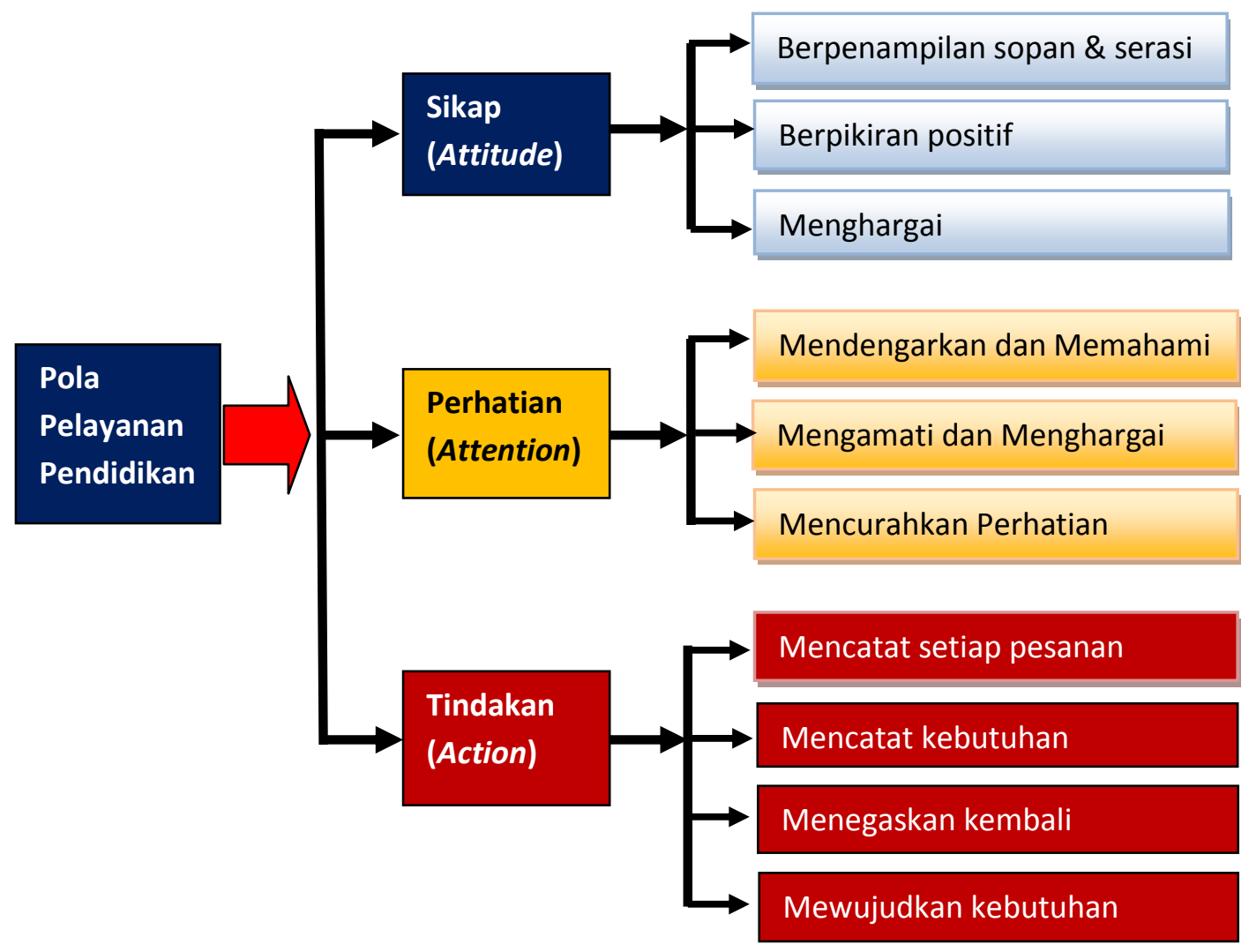

Gambar 4. Pola Pelayanan Pendidikan

1) Sikap (Attitude). Pelayanan jasa pendidikan berdasarkan konsep sikap meliputi tiga prinsip yaitu pertama melayani pelanggan berdasarkan penampilan yang sopan dan serasi, kedua melayani pelanggan dengan berpikiran positif, sehat dan logis, dan ketiga melayani pelanggan jasa pendidikan dengan sikap menghargai.

2) Perhatian (Attention). Pelayanan prima jasa pendidikan berdasarkan konsep perhatian meliputi tiga prinsip yaitu, pertama mendengarkan dan memahami kebutuhan pelanggan jasa pendidikan secara sungguh-sungguh, kedua mengamati dan menghargai perilaku

\footnotetext{
${ }^{21}$ Atep Adya Barata, Dasar-Dasar Pelayanan Prima, (Jakarta: Elex Media Komputindo,
} 2003), 58. 
pelanggan jasa pendidikan, dan ketiga mencurahkan perhatian sepenuhnya kepada pelanggan jasapendidikan

3) Tindakan (Action). Pelayanan prima pendidikan berdasarkan konsep tindakan meliputi lima prinsip, yaitu: a) mencatat setiap pesanan dari pelanggan jasa pendidikan, b) mencatat kebutuhan pelanggan jasa pendidikan, c) menegaskan kembali kebutuhan pelanggan jasa pendidikan, d) mewujudkan kebutuhan pelanggan jasa pendidikan, dan e) menyatakan terimakasih dengan harapan pelanggan mau kembali menyerap atau menggunakan produk jasa pendidikan.

Dalam perspektif Islam, pelayanan yang baik dan berkualitas dilandasioleh: ${ }^{22}$ 1) Shiddiq atau tidak pernah berdusta dalam melakukan berbagai macam layanan pendidikan serta tahanuji, ikhlas dan memiliki keseimbangan emosional-spiritual. 2) Kreatif, berani, dan percayadiri untuk mencari dan mengemukakan peluang usaha yang baru, prospektif, dan berwawasan masa depan, namun tidak mengabaikan prinsip kekinian. 3) Amanah dan fathanah yang bermakna sebagai bertanggung jawab, transparan, tepat waktu, memiliki visi, cerdas serta produktif dan berkelanjutan.4) Tabligh atau mampu berkomunikasi dengan baik atau dalam bahasa manajemen sebagai supel, cerdas, deskripsi tugas, delegasi wewenang, kerja tim (team work), cepat tanggap, koordinasi, kendali, dan supervise.5) Istiqomah Yaitu konsisten menampilkan dan mengimplementasi nilainilai di atas.

\section{Pemimpin yang Dipercaya Masyarakat}

Strategi membangun kepercayaan masyarakat melalui pemimpin lembaga pendidikan dasar Islam (LPDI) salah satunya dengan memberikan kesempatan kepada masyarakat untuk berbicara dan berani melaporkan keadaan yang sesungguhnya serta merespon

\footnotetext{
${ }^{22}$ Didin Hafidudin dan Hendri Tanjung, Manajemen Syari'ah Dalam Praktik, (Jakarta: Gema Insani, 2003), 56.
} 
positif laporan tersebut sebagai bahan evaluasi perbaikan pelayanan pendidikan. Pemimpin harus bisa mendengar keluhan yang disampaikan dengan jujur dan tanpa rasa malu serta tidakakan mempermalukan stake holdernya sendiri. Bila masyarakat sudah mulai mengeluh, pimpinan yang baik harus mendiagnosa secara tepat dan bisa memberikan solusi terbaik untuk mengatasinya. Seperti yang digambarkan Stephen R.Covey dalam bukunya "The Speed of Trust: The One Thing that Changes Everything". Terdapat 5 gelombang trust atau kepercayaan:

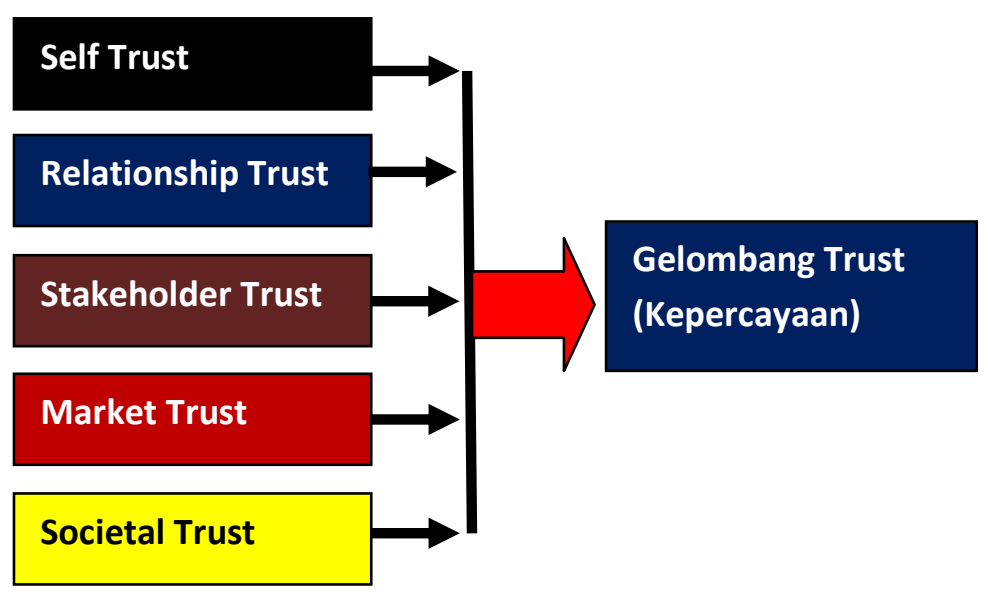

\section{Gambar 5. Gelombang Trust (Kepercayaan)}

a Self Trust, percaya kepada diri sendiri, bahwa sebagai pemimpin mempunyai integritas yang tinggi, mempunyai tujuan baik dalam menjalankan kepemimpinannya, pernyataannya selalu sempurna dan memiliki track records yang mengagumkan, ini biasa disebut dengan "Poros Kredibilitas".

b. Relationship Trust, di sini diperlukan adanya tingkah laku organisasi lengkap dengan jajarannya secara konsisten dan berkesinambungan.

c. Stakeholder Trust, setiap organisasi yang dipimpinnya tidak diperkenankan untuk melindungi, tetapi harus berani menjamin 
kualitas dari para anggota organisasi dengan memberikan kepercayaan yang sangat tinggi. Disini diterapkan adanya prinsip-prinsip kerja sama dalam membangun organisasi.

d. Market Trust, dipergunakan dengan menggunakan prinsip reputasi, keunggulan branding image dan menunjukan bukti nyata, bahwa apa yang disampaikan ada buktinya dan produk yang dihasilkan laku jual.

e. Societal Trust, pemimpin harus mampu memelihara kepercayaan yang diberikan oleh masyarakat dengan memberikan kembali kepercayaan itu dalam bentuk proses pemberdayaan yang dinamis dan berkelanjutan.

Pemimpin selain harus memiliki pengetahuan dan keterampilan untuk memimpin juga dituntut berperilaku sebagai panutan bagi bawahannya (building the trust).Arie de Geus mengemukan bahwa organisasi yang bisa bertahan lebih dari seratus tahun dan menunjukkan prestasi yang outstanding adalah organisasi yang dipimpin oleh pemimpin yang teach by example. Dalam konteks organisasi publik, kepemimpinan merupakan 'kepemimpinan formal' dalam arti pemimpin diangkat dan dikukuhkan untuk menduduki jabatan tertentu. Pada kondisi demikian, akuntabilitas (accountability) sebagai kemampuan untuk menjelaskan dan menjawab segala hal yang menyangkut langkah dan proses yang dilakukan serta pertanggungjawaban atas kinerjanya menjadi penting. Selain itu, kepemimpinan lembaga pendidikan dasar Islam harus didasarkan pada kredibilitas yang dibentuk atas dasar profesionalitas dan kejujuran. Kejujuran dalam kepemimpinan merupakan akar dan modal dari terhindarnya tindakan yang bertentangan dengan norma-norma kehidupan, baik yang dilakukan oleh para pemimpin itu sendiri maupun para pengikutnya.

Kepemimpinan merupakan fenomena sosial, yang berarti bahwa praktek kepemimpinan dipengaruhi nilai-nilai (value-driven). 
Dalam pelayanan publik, nilai-nilai yang mendasari seorang pemimpin transformasional bertindak adalah customer satisfaction. Langkah yang dapat ditempuh seorang pemimpin dalam untuk menciptakan pelayanan prima antara lain: 1) Mengembangkan call centers dalam pelayanan kepada publik. 2) Resource sharing atau melibatkan sektor swasta dalam penyediaan pelayananpublik. 3) Konsultasi publik (citizen consultation) dalam mengembangan sistem atau kebijakan yang berkaitan dengan pelayanan publik.

Dalam melakukan berbagai strategi peningkatan pelayanan seperti tersebut di atas, itu diperlukan kepemimpinan yang mampu membangun visi bersama (shared-vision).Beberapa karakteristik pimpinan visioner dalam pelayanan publik, yaitu:

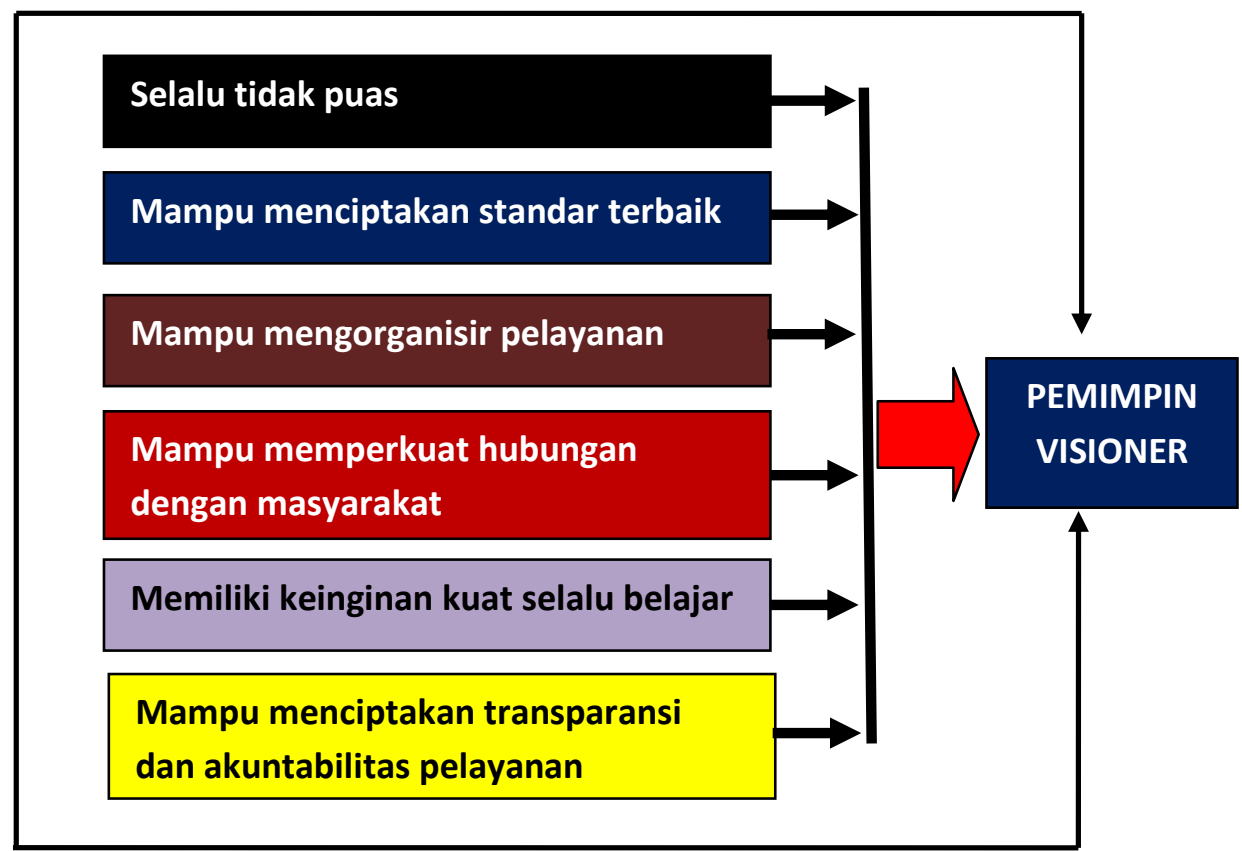

Gambar 6. Karakteristik Pemimpin Visioner

a. Selalu tidak puas. Selalu memiliki keinginan untuk melakukan peningkatan lebih baik sesuai dengan lingkungan yang selaluberubah.

b. Mampu menciptakan standard terbaik menurut visinya. Yaitu mengembangkan suatu visi strategis dalam bidang pelayanan yang 
mencerminkan budaya, aspirasi dan nilai-nilai dalam organisasi.

c. Mampu mengorganisir pelaksanaan pelayanan secara efektif, yaitu ketika kebijakan dapat dilaksanakan untuk mencapai tujuan yang diinginkan dengan cara menggerakkan secara top-down dan juga struktur organisasi secara horizontal.

d. Mampu memperkuat hubungan dengan masyarakat dengan menggunakan teknologi terbaru untuk memaksimalkan pelayanan secaraonline.

e. Memiliki keinginan kuat untuk selalu belajar,baik dari keberhasilan organisasi lain dalam pelayanan maupun belajar dari kesalahan yang merekalakukan.

f. Mampu menciptakan transparansi dan akuntabilitas dalam pelayanan, termasuk akuntabilitas dan transparansi yang bersifat multiple government alorganizations.

\section{Pengembangan Sumber Daya Manusia}

Salah satu bidang penting dalam manajemen pendidikan berkaitan dengan sumber daya manusia (SDM) yang terlibat dalam proses pendidikan. Hal ini sejalan dengan pernyataan Sergiovanni, et.al, yang menyatakan bahwa: "Perhaps the most critical difference between the school and most other organization is the human intensity that characterize its work. School are human organization in the sense that their products are human and their processes require the sosializing of humans". ${ }^{23} \mathrm{Hal}$ ini menunjukan bahwa masalah SDM menjadi hal yang sangat dominan dalam proses pendidikan di lembaga pendidikan dasar Islam.

Wherther and Davis, menyatakan bahwa SDM dalam konteks manajemen adalah "people who are ready, willing, and able to

${ }^{23}$ Sergiovanni, Thomas J. 1984. "Leadership and Excellent Scholling". Educational Leadership, February, 1984, Vol. 41, No. 5. dalamhttp://uharsputra.wordpress.com. 
contribute to organizational goals". ${ }^{24}$ SDMLPDI adalah: (1) tenaga pendidik, terdiri pengajar/guru, konselor dan pelatih; (2) tenaga fungsional kependidikan, terdiri atas penilik, pengawas, peneliti dan pengembang kependidikan, dan pustakawan; (3) tenaga teknis kependidikan, terdiri atas laboran dan teknisi sumber belajar;(4) tenaga pengelola terdiri atas kepala sekolahdan pimpinan satuan pendidikan luar sekolah; dan (5) tenaga lain yang mengurusi masalah-masalah manajerial atau administratif kependidikan.

Mulyati mengutip pendapat Mondy, Noe, dan Premeaux menyatakan bahwa pengembangan SDM dapat dilakukan melalui: (1) pelatihan (training), (2) pengembangan (development), pengembangan karir (career development), dan (4) penilaian kinerja (performance apprasial). ${ }^{25}$

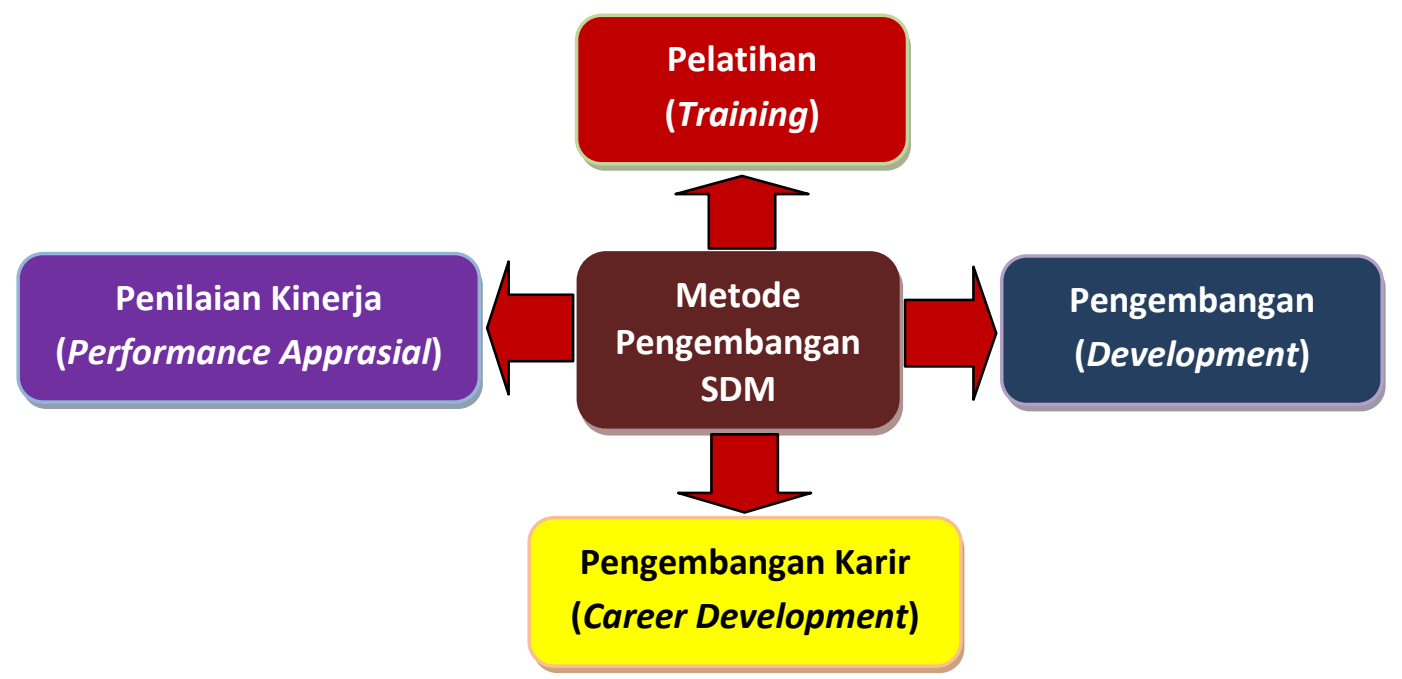

Gambar 7: Metode Pengembangan SDM Pendidikan Islam

Pelatihan (training) merupakan kegiatan yang memberikan kesempatan belajar untuk meningkatkan pengetahuan dan keahlian yang diperlukan pada pekerjaan yang sedang dijalani atau yang terkait

\footnotetext{
${ }^{24} \mathrm{Ibid}$.

${ }^{25}$ Deti Mulyati, Manajemen Pengembangan Sumber Daya Aparatur Eselon III Dalam Rangka Peningkatan Kinerja Individu. Disertasi.(Bandung: Universitas Pendidikan Indonesia, 2012.), 46.
} 
dengan pekerjaannya. Pengembangan (development) meliputi kesempatan belajar yang bertujuan untuk lebih meningkatkannya. Pengembangan lebih difokuskan pada pengembangan karir (career development), merupakan pendekatan formal yang digunakan untuk menjamin bahwa orang dengan kualifikasi tepat dan berpengalaman tersedia pada saat dibutuhkan. Sedangkan penilaian kinerja (performance apprasial) adalah sistem formal dan review periodik dan evaluasi kinerja individu atau tim. ${ }^{26}$

Pengembangan tenaga kependidikan berbasis kinerja dapat meningkatkan suasana kondusif dalam bekerja, sehingga tujuan pengembangan SDM dapat tercapai, yaitu: (1) meningkatkan produktivitas kerja; (2) mencapai efisiensi; (3) meminimalisasi kekurangan/kelemahan; (4) meningkatkan pelayanan; (5) memelihara moral pegawai; (6) meningkatan peluang karir; (7) meningkatkan kemampuan konseptual; (8) meningkatkankepemimpinan; peningkatan balas jasa. ${ }^{27}$ Ketercapaian tujuan pengembangan SDM tersebut berdampak pada tercapainya mutu unggul lembaga. Keunggulan ini tampak pada semua aspek dan menyeluruh meliputi semua komponen karena keunggulan itu bersifat multidimensi dan holistik. $^{28}$

\section{Pameran Pendidikan}

\section{a. Pengertian Pameran}

Pameran merupakan penyebaran pesan informatif, persuasif dan sebagai sarana komunikasi yang membuat masyarakat tetap menjadi ingat dan mengerti tentang apa yang di tampilkan pada pameran tersebut. Penyebaran pesan melalui pameran, akan membentuk pengetahuan masyarakat tentang apa saja yang telah ditampilkan oleh madrasah. Kemudian pengetahuan tersebut dapat

\footnotetext{
${ }^{26}$ Deti Mulyati, Manajemen......, 47.

${ }^{27}$ Eris Yustiono. 2012. "Pengembangan SDM". Makalah.http://www.stialan bandung.ac.id.

${ }^{28}$ Thomas J. Sergiovanni, Leadership and Excellent Scholling.Educational Leadership,

February, 1984, Vol. 41, No. 5. hal.6.
} 
diserapmelalui indara manusia yang dapat mempengaruhi ingatan pengunjung pameran.seperti yang diungkapkan oleh Ruslan bahwa pengetahuan yang diserap oleh indra manusia meliputi: Mata (sight) 70\% pendengaran (hearing) $13 \%$ sentuhan (touch) $6 \%$ penciuman (smell) 3\% dan Cita Rasa (taste) 3\%dan unsur-unsur indra manusia ini digunakan dalam pameran ${ }^{29}$.

Dalam hubungan masyarakat, pameran merupakan kegiatan yang menunjukkan sesuatu kepada orang banyak mengenai kelebihan dan keunggulan yang dimiliki oleh sesuatu tersebut ${ }^{30}$.Dalam bidang pendidikan pameran lembaga pendidikan dasar Islam merupakan upaya penampilan kelebihan dan keunggulan yang dimiliki oleh madrasah untuk diketahui, dipahami, sehingga timbul simpati bahkan empati bagi yang menyaksikan pameran tersebut.

\section{b. Tujuan Pameran}

Tujuan pameran madrasah (LPDI) adalah memberikan informasi tentang program-program dan kegiatan yang telah dicapai oleh madrasah kepada pengunjung (masyarakat) dengan harapan pengunjung tertarik dengan program-program yang dilakukan madrasah tersebut. Adapun pelaksanaan pameran bertujuan mengenalkan, membangun image, dan citra sebuah lembaga pendidikan yang pada akhirnya akanmenimbulkan kepercayaan terhadap lembaga pendidikan tersebut. Secara spesifik tujuan diadakannya pameran di antaranya:

1) Mengenalkan nama lembaga pendidikan agar lebih akrab di telinga masyarakat

2) Mengenalkan visi misi pendidikan yang berkaitan dengan kemajuan zaman

3) Mengenalkan prestasi yang diraih dalam even-even nasional

${ }^{29}$ Rosady Ruslan, 2002. Manajemen Humas Konsepsi dan Komunikasi Konsepsidan Aplikasi, (Jakarta: Grafindo Persada, 2002), 245.

${ }^{30}$ lbid, 246. 
maupun internasional.

4) Menarik pengunjung pameran untuk mempercayaakan pendidikan putra-putrinya ke lembaga pendidikan dengan menampilkan produk dan atraksi hasil karya siswanya

5) Mengenalkan beberapa keunggulan yang dimiliki oleh lembaga pendidikan kepada pengunjung pameran dibanding dengan pendidikan yang lain.

6) Menciptakan pencitraan terhadap lembaga yang dipromosikan atau dipamerkan.

\section{c. Mekanisme Pameran}

Beberapa yang perlu dipersiapkan berkaitan dengan pelaksanaan acara adalah:

1) Madrasah memberikan pesan-pesan kepada setiap calon peserta pameran (pengunjung). Dalam hal ini mediahumas yang digunakan adalah pos (stand) ataupusat penerangan yang melayani segenap peserta dan pengunjung pameran terutama dari kalangan media masa ${ }^{31}$. Baik media elektronik maupun media cetak.

2) Pada saat pameran berlangsung diperlukan adanya pemandu yang membantu menjelaskan secara verbal data-data yang ada dalam pameran. Untuk meningkatkan kualitas komunikasimaka diperlukan adanya data-data yang didukung olehpenjelasan melalui komunikasi non verbal misalkan melalui pamflet, brosur yang didisain dengan menarik dan memikat.

3) Selain pos (stand) digunakan untukmenjelaskan kepada masyarakat tentang kelebihan dan prestasi peserta didiknya, pos juga dapat digunakan sebagai tempat menampilkan berbagai demonstrasi baik pertunjukan film prestasi peserta didik maupun demontrasi prestasi secara langsung kepada pengunjung

\footnotetext{
${ }^{31}$ M. Linggar Anggoro, Teori Dan Profesi Kehumasan Serta Aplikasinya Di Indonesia, (Jakarta: Bumi Aksara, 2001), 168.
} 
pameran $^{32}$.

\section{d. Perencanaan dan Organisasi Pameran}

Jika pameran direncanakan dengan matang, maka pihak madrasah akan memiliki banyak kesempatan untuk mempromosikan lembaga pendidikannya. Karenanya pelaksanaan pameran harus mempertimbangkan beberapa hal, di antaranya ${ }^{33}$ :

1) Apakah pameran itu diselenggarakan oleh perusahaanyang terkenal ataukah tidak? hal ini untuk mengantisipasi kurangnya pengunjung jika tidak dilakukan dengan profesional, termasuk juga apakah ia sebelumnya sudah melaksanakan pameran barang ataukah yang serupa dengan pameran-pameran sosial ataukah tidak?

2) Apakah lokasi pameran mudah dijangkau mengangkut dan membawa pulang barang-barang atau benda-benda pameran? Sebab tempat pameran yang terlalu jauh biasanya menimbulkan masalah dalam pengangkutan dan sarana transportasi untuk mengunjungi pameran tersebut.

3) Apakah tempat pameran tersebut cukup bagus dan bisa menarik pengunjung yang relevan dalam jumlah yang besar?

4) Apakah tempat pameran tersebut memiliki lahan parkir yang memudahkan bagi pengunjung untuk memarkir kendaraannya dengan baik mudah danaman.

5) Publikasi panitia pameran, bagaimana publikasi yang dilakukan oleh panitia pameran apakah akan bisa menarik pengunjung ataukah tidak.

6) Apakah kunjungan petugas pers dan para wartawan diatur oleh pihak penyelenggara pameran? Sebab pers merupakan aspek pameran yang harus diperhatikan oleh setiap peserta pameran, karena melalui pameran itu mereka berminat memperoleh liputan

\footnotetext{
${ }^{32} \mathrm{lbid}, 187$.

${ }^{33}$ Soekarto Indrafahrudi, Bagaimana Mengakrabkan Sekolah dengan Orang Tua Murid dan Masyarakat, (Malang: IKIP Malang, 1994), 191-192.
} 
yang mendukungoprasional.

7) Kegiatan-kegiatan yang terkait, apakah ada kegiatan lain yang bersifat mendukung, dan berkaitan dengan pameran tersebut.

Perencanaan semakin mantap apabila ditampilkan karakteristik khusus dalam pameran lembaga pendidikan (madrasah) yang dapat menarik perhatian halayak sebagai obyek maupun subyek. Adapun karakteristik itu sebagai berikut ${ }^{34}: 1$ ) Mudah menarik perhatian misalnya dengan mengundang kalangan pers. 2) Waktu yang luang untuk menjelaskan para pengunjung. 3) Peluang percobaan prototype untuk memajang berbagai produk baru seperti karya-karya atau hasil kreatifitas siswa. 4) Peluang pertemuan tatap muka secara langsung dengan para pengunjung pameran. 5) Acara demonstrasi dan pembagian sampel. 6) Adanya suasana akrab dalam pameran yang dibuat sebagai wahana rekreasi, sehinga pengunjung merasa betah meskipun mereka berjalan kaki.

Dalam pelaksanaan pameran lembaga pendidikan maka pihakpihak yang dilibatkan meliputi: 1) Kepala madrasah, 2) Wakil kepala madrasah bagian humas, 3) Wakil kepala madrasah bagian kesiswaan, 4) Pembina Osis, 5) Guru dan Siswa.

\section{e. Bentuk-Bentuk Pameran}

Pada dasarnya bentuk-bentuk pameran yang dapat diikuti sekolah/madrasah dapat diklasifikasikan sebagai berikut ${ }^{35}$ :

1) Pameran umum (Public Exhibition) yakni pameran yang bertujuan untuk memperkenalkan organisasi, produknya, atau hal khusus kepada halayak umum.

2) Pameran di luar ruangan (Outdoor Exhibition) yakni yang menampilkan produk berukuran besar, misalnya produk-produk pertanian dan pameran pedesaan lainnya.

3) Pameran terbatas (Private Exhibition) Diadakan dalam ruang baik

\footnotetext{
${ }^{34}$ Frida Kusumatuti, Dasar-Dasar Humas, (Jakarta: Ghalia Indonesia, 2002), 191.

${ }^{35}$ Frida Kusumatuti, Dasar-Dasar ........188-189.
} 
itu dalam sebuah gedung milik sendiri mupun di gedungsewaan

4) Pameran dagang luar negeri (Overseas Trade Fairs) yang khusus diselenggarakan dalam rangka mempromosikan produk-produk buatan suatu negara di negara lain, dan menarik minat parapembeli atau importir setempat.

5) Pameran keliling (Mobile Show) yakni pameran yang biasa diselenggarakan secara berpindah-pindah dari satu tempat ke tempat yang lain dengan trailer, truk, minimbus, dan lain-lain.

6) Pameran jinjing (Portable Exhibition) yakni suatu pameran yang perangkatnya begitu ringkas sehingga mudah dibawa kemanamana. Gerai yang dipakai juga ringkas sehingga gampang dilipat serta diangkat penyelenggara.

7) Pameran kecil (Small Exhibition) yang biasa diadakan pada sebuah pojok atau sudut toko, beranda hotel, dan di emperan stasiun atau bandar udara, barang yang dipamerkan dapat dikemas dalam kotak-kotak atau diletakkan di etalase ditumpukkan pada panel pameran atau bisa juga ditempatkan pada suatu acara khusus secara permanen. Di samping panel pameran perangkat penting lainnya yang selalu digunakan adalah sampel foto dan bagan-bagan.

8) Acara pekan belanja atau pekan promosi (Shopping Weeks) yang seringkali disponsori oleh pemerintah, asosiasi perdagangan, perusahaan manufaktur, dan badan promosi pariwisata tau lembaga-lembaga lainnya. Acara ini juga sering disertai dengan pertunjukan film atau atraksi hiburan panggung dengan melibatkan para penari, penyanyi dan artis terkenal, dalam taraf internasional.

Dalam pameran madrasah, variasi di atas dapat digunakan keseluruhannya tinggal yang dipertimbangkanhanya insidental atau terencana atau terprogram, misalkan satu tahun satu kali, atau bila hanya menggunakan variasi pameran kecil seminggu sekali atau satu bulan sekali. Pameran dagang dalam hal pendidikan dapat dilakukan 
pada orang-orang penting atau kunci yang mempunyai pengaruh besar terhadap lembaga pendidikan yang bersangkutan dari sudut sosiologis. Selian itu jaga dapat menggunakan pameran jinjing, madrasah melakukan sosialisasi dengan lebih aktif bergerak. Begitu juga pameran keliling yang lebih aktif adalah pihak lembaga.Namun bila melibatkan semua pihak maka bisa menggunakan variasi-variasi yang ada di atas dan hasilnya akan maksimal.

\section{Penutup}

Berdasarkan uraian di atas, dapat disimpulkan bahwa secara hitoris pendidikan dasar Islam (madrasah) yang dirintis oleh para waliyang kemudian dikenal dengan nama Pesantren, pada masa lampau terkesan sebagai pendidikan yang konservatif dan jauh dari sentuhan kemajuan. Kondisi tersebut secara alamiah membangun image bahwa pendidikan dasar Islam identik dengan pendidikan yang terbelakang (marginal) yang hanya dikonsumsi oleh rakyat kecil (grassroot). Strategi membangun kepercayaan masyarakat pada pendidikan dasar Islam dapat dilakukan, antara lain: (a) Kejujuran, (b) Kualitas pelayanan yang baik, (c) Pemimpin yang dipercaya masyarakat, (d) Pengembangan sumber daya manusia, dan (e) Pameran pendidikan.

\section{DAFTAR PUSTAKA}

Al-Math, Muhammad Faiz. 1994. 1100 Hadits Terplih: Sinar Ajaran Muhammad, terj. A. Aziz Salim Basyarahil. Dari judul Asli Qabasun Min Nuri Muhammad. Jakarta: Gema Insani Press.

Anggoro, M. Linggar. 2001. Teori dan Profesi Kehumasan Serta Aplikasinya Di Indonesia. Jakarta: Bumi Aksara.

Barata, Atep Adya. 2003. Dasar-Dasar Pelayanan Prima. Jakarta: Elex Media Komputindo.

Bawani, Imam, 1987. Segi-Segi Pendidikan Islam. Surabaya: Al-Ikhlas,.

Dirjen Pendis. 2006. Undang-Undang dan Peraturan Pemerintah RI tentang Pendidikan. Jakarta: Dirjen Pendis Departemen Agama RI. 
Djumhur dan Danasaputra, tt.Sejarah Pendidikan Islam. Bandung: IImu.

Hafidudin, Didin dan Hendri Tanjung.2003. Manajemen Syari'ah Dalam Praktik. Jakarta: Gema Insani.

Indrafahrudi, Soekarto. 1994. Bagaimana Mengakrabkan Sekolah dengan Orang Tua Murid dan Masyarakat. Malang: IKIP Malang.

Kasmir.2011. Etika Customer Service.Jakarta: Raja Grafindo Perssada.

Kusumatuti, Frida. 2002. Dasar-Dasar Humas. Jakarta: Ghalia Indonesia.

Lembaga Administrasi Negara RI. 2006. Strategi Peningkatan Kualitas Pelayanan Publik. Jakarta: LAN RI.

Mulyati, Deti. Manajemen Pengembangan Sumber Daya Aparatur Eselon III Dalam Rangka Peningkatan Kinerja Individu.Disertasi. Bandung: Universitas Pendidikan Indonesia, 2012, hal.46.

Mustofa, Ahmad dan Abdullah Ali. 1997. Sejarah Pendidikan Islam di Indonesia. Bandung: CV. Pustaka Setia.

Nata, Abuddin. 2012. Manajemen Pendidikan. Jakarta: Kenacana Predana Media Group.

Pusat Bahasa Departemen Pendidikan Nasional.2001. Kamus Besar Bahasa Indonesia. Jakarta: Balai Pustaka.

Ratmino dan Atij Septi Winarsih. 2009. Manajemen Pelayanan. Yogyakarta: Pustaka Pelajar.

Ruslan, Rosady. 2002. Manajemen Humas Konsepsi dan Komunikasi Konsepsidan Aplikasi. Jakarta: Grafindo Persada.

Sergiovanni, Thomas J. 1984. "Leadership and Excellent Scholling". Educational Leadership, February, 1984, Volume 41, No. 5. Hal.6 dalam http://uharsputra.wordpress.com.

Siagian, Sondang P. 1995. Manajemen Stratejik. Jakarta: Bumi Aksara.

Toruan, Rayendra L. 2004. Dasar-Dasar Pelayanan Prima. Jakarta: PT Elex Media Komputindo.

Yaqien, Nurul. 2010. "Membangun Kepercayaan Masyarakat Pada Madrasah Melalui Pameran Pendidikan", dalam jurnal Madrasah, Volume 11, Nomor 2, Januari-Juni 2010, hal. 194.

Yustiono, Eris. 2012. "Pengembangan SDM". Makalah.http://www.stialan bandung.ac.id. 